\title{
LA RELIGIÓN GIVIL ¿COHERENCIA O CONTRADICCIÓN DEL PENSAMIENTO ROUSSONIANO?
}

\author{
Marta GARCIA ALONSO \\ Dpto. Filosofia Moral y Politica. UNED
}

Ghislain WaTERLOT, Rousseau. Religion et politique, París: PUF, 2004.

Una forma de volver sobre los clásicos es analizar aquellos aspectos de su obra que más acuciantes resultan en nuestro presente. Nadie negará que Rousseau cumple con la primera condición y la dimensión política de la religión es una de esas cuestiones que hoy más nos importan. A partir de su tesis doctoral, Ghislain Waterlot explora en Rousseau. Religion et politique algunas de los interrogantes con los que resulta hoy inevitable abordar al filósofo ginebrino.

Se trata de un breve ensayo de 124 páginas dividas en cuatro epígrafes principales y una reflexión final sobre la actualidad de la religión civil. El primero de estos epígrafes titulado Religión y politica: el vinculo necesario (pp. 7-15) sirve para presentar el problema que se analizará a lo largo de las páginas que siguen. $\mathrm{Al}$ establecer la necesidad de la religión en la fundación y cohesión del Estado el problema a que se enfrenta Rousseau es, ni más ni menos, el de compatibilizar la religión natural expresada en La profesión de fe del Vicario saboyano con la religión civil del El Contrato social; es decir, reconciliar las máximas morales del Evangelio (coincidentes con la religión natural) con el dogma de la santidad del contrato social y de las leyes (p. 11).

$\mathrm{Y}$ es que, como Waterlot muestra en este ensayo, el mismo Rousseau que seńala la necesidad y la capacidad de la ciudadanía en la constitución de un pacto en el que establece su voluntad de someterse a una ley que preserve su libertad política es, paradójicamente, quien nos advierte sobre la imposibilidad de 
que sea esa ciudadanía la que elabore dicha legislación. Se necesita «un hombre extraordinario en el Estado" para llevar a cabo esa tarea. (CS II, 7). Este es el tema que se desarrolla en el segundo de los capítulos, El legislador y el origen de la religión (pp. 15-31).

La dificultad de premisas semejantes se muestra en sus consecuencias: el pueblo no tiene capacidad para reconocer la voluntad general, de modo que el legislador tiene por función expresarla y darsela a conocer. Sin embargo, a pesar de no poder legislar, la ciudadanía es quien tiene el derecho legislativo primario y nada le puede venir impuesto. ¿Cómo superar esta aporía? Como señala Waterlot (p. 19), Rousseau introduce la religión como el único medio de aunar autoridad y legislación, puesto que mediante la apelación al milagro, a la inspiración divina, es como ha resultado históricamente posible que la labor del legislador real sea apreciada y conservada:

Así pues, no pudiendo emplear el legislador ni la fuerza ni el razonamiento, tiene por necesidad que recurrir a una autoridad de otro orden, que pueda arrastrar sin violencia y persuadir sin convencer. He aquí lo que obligó en todos los tiempos a los padres de las naciones a recurrir a la intervención del cielo y a honrar a los dioses con su propia sabiduría, para que los pueblos sometidos a las leyes del Estado y a las de la Naturaleza y reconociendo el mismo poder en la formación del hombre y en la del Estado, obedeciesen con libertad y llevasen dócilmente el yugo de la felicidad pública. (CS II, 7; trad. de M. J. Villaverde)

No es ningún dios quien inspira la legislación, pero es necesario apelar a la religión para instituir un Estado legítimo puesto que, en último término, sólo una moralidad como la que se funda en la fe puede sostener las bases de un Estado fuerte y su legislación y "hacer aceptable el sacrificio de la vida por la ciudad» (p. 27). He aquí el elemento clave de la función de la religión: compatibilizar deberes políticos y derechos subjetivos, diríamos hoy.

Sin embargo, históricamente las religiones han tenido pretensiones políticas y el cristianismo no ha sido una excepción en esto. Es, precisamente, el análisis del lugar del cristianismo el que ocupa el tercer epígrafe cuyo rótulo es significativo Del paganismo al cristianismo: la figura de Jesús (pp. 31-62). Nada más contrario a la religión civil y al Estado que un cristianismo institucionalizado con 
pretensiones totalizadoras. De modo que nada más urgente que disociar religión y política. En las páginas citadas, Waterlot muestra el mecanismo del que se sirve el filósofo ginebrino para establecer esa disociación. Su propósito será salvaguardar la moralidad evangélica que, a ojos de Rousseau, resulta coincidente con los principios de la religión natural fundada por la razón y liberar al Estado de la tiranía de una religión con ambiciones políticas.

Por último, el cuarto epígrafe enfrenta la tarea de mostrar hasta qué punto los principios de la religión civil resultan aporéticos o, por el contrario, son coherentes con el pensamiento político roussoniano. Bajo el título ¿Aporías de la religión civil? (pp. 62-113) Waterlot reivindica la coherencia del filósofo puesto que si bien parece contradictorio que Rousseau aune en su pensamiento religión civil y religión natural — caracterizada por ser apolítica-, dicha contradicción desaparece si tenemos en cuenta que la reunión de estos dos tipos de religión tan diferentes provoca la aparición de un elemento nuevo en el cual ninguno de los componentes originarios puede ser reconocido (p. 90). Según Waterlot, Rousseau es consciente de que la religión civil es, ni más ni menos, una invención, una nueva profesión de fe puramente civil cuya función principal es sostener y fundamentar la santidad del contrato social y de las leyes del Estado. Al decir de Waterlot, Rousseau considera que, para establecer una religión civil moderna, es preciso sintetizar la religión del hombre (natural) y la religión del ciudadano, no crear un catecismo del ciudadano a lo Voltaire (p. 92).

El ensayo se cierra con un análisis sobre la actualidad del problema. Las páginas recogidas bajo el titulo Sentido y actualidad de la religión civile (113-124). La religión civil roussoniana es la fórmula para hacer compatible moral y política, derechos individuales y deberes colectivos. Se trata de la receta para conciliar al hombre y al ciudadano mediante la disolución de ambos conceptos en un tercero nuevo que permita un patriotismo moderado que no disuelva al individuo en la comunidad y, al tiempo, aporte un fundamento cuasi-sacro de las leyes de la ciudad al remitirlas a una moral religiosa-natural (p. 115).

En suma, como señala el propio Waterlot (p. 5), la religión constituye un serio problema en la obra de Rousseau puesto que, como es sabido, el contrato social se constituye sin referencia alguna a ambitos ontológicos o institucionales ajenos al Estado. Sin embargo, la religión civil se inventa para facilitar la obra del legislador, así como para establecer las bases de la cohesión social haciendo com- 
patibles los deberes políticos y los derechos individuales. Ciertamente, no será la religión pieza clave en la fundación del pacto social pero, aunque resulte paradójico, seguirá siendo uno de los elementos decisivos en la constitución de la identidad comunitaria. Un Estado necesita fundar los deberes cívicos en una moral fuerte y sólo una moralidad como la religiosa puede solicitar legítima y coherentemente el sacrificio de sus ciudadanos, que no puede ser impuesto de modo absoluto por el Estado, sin más. Como ya defendiera Hobbes, sólo la religión puede justificar el sacrificio del individuo por su comunidad, y esta accion sólo puede derivarse de la ley natural relativa a la gratitud que, si bien no es un principio de la razón, sí es un principio escriturario ${ }^{1}$. La religión, expulsada por la puerta, vuelve a entrar por la ventana.

Como puede apreciarse en esta breve nota, la virtud de este breve ensayo que comentamos no es solamente la de ser un excelente trabajo académico sobre uno de los filósofos políticos más importantes de todos los tiempos. Además, tiene la virtud de mostrarnos un Rousseau actualizado, cercano, que tiene mucho que decir al lector contemporáneo que intente analizar, por ejemplo, algunos ingredientes del actual programa político de los EE. UU. en su lucha contra el Gran Satán.

Así como la función del legislador roussoniano es la de traducir la voluntad general en normas que el pueblo pueda asumir voluntaria y libremente, así también la lectura de Leo Strauss que al parecer hoy se propone en Washington convierte al político en intérprete de una voluntad popular incapaz de autolegislarse.

Por otra parte, cada vez parece más audible en Washington el principio de que sólo una moral fuerte - religiosa - puede fundar un derecho político sólido en casos críticos como una guerra. Sólo una legislación fundada en principios morales fuertes puede legitimar aquellos casos en que los deberes políticos entran en contradicción con los individuales. Una versión revisada del clásico pro patria mori en el que se incorpora la moral individual cristiana como fundamento de derechos subjetivos inalienables. En nuestros días muchos de los conceptos de la

${ }^{1}$ Cf. en este sentido nuestra nota sobre J. M. Hernández: El retrato de un dios mortal. Estudio sobre la filosofia polttica de Thomas Hobbes (Barcelona: Anthropos, 2002) en Isegoria, 28 (2003), pp. 282-287. 
religión civil roussoniana han perdido o atenuado sus referentes religiosos pero las funciones que éstos representaban permanecen cuanto menos traducidas en las nuevas versiones de esta religión civil moderna. Tal vez no sea absurdo pensar que continúan arrastrando muchas de sus contradicciones... 